\title{
Examination of Applicants for Home Purchase Subsidy for Families in Terms of Prior Commitment to Having Children and Extent of Property Acquisition, Based on the Data of a Credit Institution*
}

\author{
Kata Plöchl-Csilla Obádovics
}

By examining a credit institution's database for the period 2016-2020, the authors aimed to discover the extent to which Home Purchase Subsidy (HPS) for families applicants use the subsidy received in return for committing to having children in Hungary. The current study also examines which social groups the HPS provides essential assistance to with home purchasing, and at which income level and property value the subsidy motivates the purchase of a second home. Using cluster analysis, the authors found that groups with modest incomes and housing are the most likely to commit to having children in advance. Though the subsidy assists this group the most with housing, the amount received from the subsidy is small. Moreover, the current study revealed that 8 per cent of applicants used the subsidy to purchase a second property.

Journal of Economic Literature (JEL) codes: H31, G51, R21, J13

Keywords: HPS, housing subsidy, family support, housing need, childbearing willingness

\section{Introduction}

The importance of home ownership in Hungary dates back to the socialist regime. For 80 per cent of Hungarian families, a privately owned residential home is not only the main asset, it also represents a secured standard of living that is often the result of several generations of work. In accordance with European traditions, Hungary is currently engaged in a universal redistribution program, one with economic and social dimensions (Dániel 1997; Dániel 2004; Csermák 2011; Levi 1993; Rothstein 1998; Bényei 2011; Kováts 2007; Békés et al. 2016). As part of the program, the state assumes an allocation role in developing higher quality home ownership. Assuming self-provision, the subsidy scheme allocates public funds to existing private capital with the aim of making housing objectives more affordable (Sági et al. 2017; Maleque 2019).

* The papers in this issue contain the views of the authors which are not necessarily the same as the official views of the Magyar Nemzeti Bank.

Kata Plöchl is a PhD student at the István Széchenyi Management and Organisation Sciences Doctoral School of the Alexandre Lamfalussy Faculty of Economics of Sopron University. Email: plochl.kata@gmail.com Csilla Obádovics is a University Professor of the Alexandre Lamfalussy Faculty of Economics of Sopron University. Email: obadovics.csilla@uni-sopron.hu

The Hungarian manuscript was received on 11 March 2021.

DOI: http://doi.org/10.33893/FER.20.3.80109 
Hungarian housing policy has oscillated between extensive periods supporting home ownership and lean periods during which home ownership was barely addressed at all. Housing policy measures taken while a government is in office generally extend well beyond an election cycle, which, due to the protracted nature of housing subsidies - difficult to calculate and particularly hard to regulate - underscores the significance of responsible policy making.

Opinions concerning a subsidy scheme's degree of differentiation vary; however, the consensus holds that any potential subsidy scheme should be selective, long-term, and sustainable. Such a subsidy may operate efficiently in a global framework of home construction, improvement, maintenance and funding and, in addition to the short-term objectives, sets clear medium- and long-term targets for all economic agents under the prevailing housing situation (Csermák 2011; Mayo 1993).

The Hungarian government has addressed the country's demographic issues in a comprehensive manner since 2010. In this sense, the current Hungarian family policy has a dual objective. On the one hand, it aims to help young people bear as many children as they wish. On the other hand, it also strives to support those who already have children (Novák 2020). The policy acknowledges that demography has a major impact on the future of countries (Singhammer 2019). The importance of demographic objectives is evidenced by the fact that the fertility rate in Hungary but also across Europe - is declining, and thus so is the population (Beaujouan et al. 2017; Dorbritz - Ruckdeschel 2007; Neyer et al 2016). The overarching goal behind demographic policies is the revival of childbearing willingness, which will reverse the declining fertility rate and contribute to population growth (Sobotka 2017). Lesthaeghe (2011) identifies the existence of a home as a key factor influencing demographic trends. Housing policy, in terms of both the quality and quantity of new housing, has a positive impact on the number of children born (Fitoussi et al. 2008). The incentive is even greater if the housing subsidy is coupled with preferential loans due to the flow of families with children to settlements on the fringes of cities, which has a positive effect on the agglomeration population trends (Székely 2020).

\section{Features of the 2016 new housing policy; key changes since its introduction}

The improved performance and greater fiscal stability facilitated the launch of a more intensive housing policy campaign. The government launched the current Family Protection Action Plan in 2016, building upon the meagre housing policy that had been in place since 2005. The programme does not stray from the ambitions of previous housing policies (Hegedüs 2006; Kiss - Vadas 2006; Mádi 2008, 2017). More specifically, it continues to prioritise the purchase of new property, but also focuses on the purchase and improvement of used homes. In addition to supporting the creation of new homes, its objectives include the encouragement of childbearing (Szikra 2016), boosting construction, improving the property market (Tóth Horváthné 2018), and stemming the tide of depopulation in small, rural villages. 
Table 1 lists the eligibility criteria for the HPS for families. These conditions are stipulated in Government Decrees $16 / 2016^{1}$ and $17 / 2016^{2}$ and in their respective amendments.

\begin{tabular}{|c|c|c|}
\hline CONDITION & \multicolumn{2}{|c|}{ STATUTORY REQUIREMENT } \\
\hline Eligible applicants & \multicolumn{2}{|c|}{$\begin{array}{l}\text { - Hungarian or foreign citizen } \\
\text { - member of a building community, owner of an undivided share in } \\
\text { common property (effective: Government Decree No 273/2016 (IX. 15.)) }\end{array}$} \\
\hline $\begin{array}{l}\text { Eligible applicant based on } \\
\text { age }\end{array}$ & \multicolumn{2}{|c|}{$\begin{array}{l}\text { - 18-40 years: for existing and anticipated child } \\
\text { - over } 40 \text { years: only for existing child }\end{array}$} \\
\hline $\begin{array}{l}\text { Applicant's place of } \\
\text { residence or documented } \\
\text { proof thereof }\end{array}$ & \multicolumn{2}{|c|}{$\begin{array}{l}\text { - registered residence in Hungary } \\
\text { - residence permit in Hungary that extends beyond } 3 \text { months } \\
\text { - immigration permit }\end{array}$} \\
\hline Applicant's marital status & \multicolumn{2}{|c|}{ - married, cohabitation, single, divorced, widowed } \\
\hline Comfort level of the property & \multicolumn{2}{|c|}{ - suitable to meet housing needs } \\
\hline $\begin{array}{l}\text { Employment-related } \\
\text { requirements }\end{array}$ & \multicolumn{2}{|c|}{$\begin{array}{l}\text { - at least one partner must be employed upon application. } \\
\text { - legal relationship for auxiliary activity (effective: Government Decree } \\
\text { No 686/2020 (XII. 29.)) }\end{array}$} \\
\hline $\begin{array}{l}\text { Existence of prescribed } \\
\text { minimum period of } \\
\text { continuous social insurance } \\
\text { relationship (interrupted for } \\
\text { no more than } 30 \text { days) }\end{array}$ & \multicolumn{2}{|c|}{$\begin{array}{l}\text { - } 180 \text { days in the case of } 1-2 \text { child/children } \\
\text { - } 365 \text { days in the case of } 3 \text { children } \\
\text { - } 180 \text { days in the case of used property, irrespective of number of children } \\
\text { - } 365 \text { days in the case of applicants in a favoured small region (effective: } \\
\text { Government Decree No } 109 / 2019 \text { (V. 13.)) }\end{array}$} \\
\hline Subsidy may be used for & \multicolumn{2}{|c|}{$\begin{array}{l}\text { - construction or purchase of new property, purchase of used property } \\
\text { - expansion of existing property with at least one room (without new } \\
\text { commonhold unit title) } \\
\text { - development of new living quarters: loft conversion, adding a storey to } \\
\text { the house } \\
\text { - in the case of favoured small regions, also for renovation (effective: } \\
\text { Government Decree No } 109 / 2019 \text { (V. 13.)) }\end{array}$} \\
\hline Age of supported child & \multicolumn{2}{|c|}{$\begin{array}{l}\text { - 24-week foetus, up to } 20 \text { years of age } \\
\text { 12-week foetus, up to } 25 \text { years of age (effective: Government Decree } \\
\text { No } 273 / 2016 \text { (IX. 15.)) }\end{array}$} \\
\hline Supported children include & \multicolumn{2}{|c|}{$\begin{array}{l}\text { - own child, foster child, child adopted by the applicant } \\
\text { - child under the applicant's guardianship for minimum } 1 \text { year (effective: } \\
\text { Government Decree No 273/2016 (IX. 15.)) }\end{array}$} \\
\hline $\begin{array}{l}\text { Ownership in subsidised } \\
\text { property may be held }\end{array}$ & \multicolumn{2}{|c|}{$\begin{array}{l}\text { - only by the supported person(s) } \\
\text { - by the supported person's child through inheritance (effective: } \\
\text { Government Decree No 686/2020 (XII. 29.)) } \\
\text { - in the case of married couples (cohabitants) it must be owned jointly } \\
\text { by the partners }\end{array}$} \\
\hline Minimum floor area & New flat (house) & Used property \\
\hline for 1 child & $40(60) \mathrm{m}^{2}$ & $40 \mathrm{~m}^{2}$ \\
\hline for 2 children & $50(70) \mathrm{m}^{2}$ & $50 \mathrm{~m}^{2}$ \\
\hline for 3 children & $60(80) \mathrm{m}^{2}$ & $60 \mathrm{~m}^{2}$ \\
\hline for 4 or more children & $60(80) \mathrm{m}^{2}$ & $70 \mathrm{~m}^{2}$ \\
\hline
\end{tabular}

${ }^{1}$ Government Decree No 16/2016 (II. 10.) on the state subsidy for the construction and purchase of new homes

${ }^{2}$ Government Decree No 17/2016 (II. 10.) on the Home Purchase Subsidy for Families for the purchase and extension of used homes 
Subsidy exclusions and restrictions to reduce the number of opportunistic applicants were also introduced (Table 2). Nevertheless, the majority of these restrictions have been eased or cancelled since their introduction.

\begin{tabular}{|c|c|}
\hline CONDITION & STATUTORY REQUIREMENT \\
\hline Disqualifying reasons & $\begin{array}{l}\text { - outstanding taxes and dues } \\
\text { - Central Credit Information System negative debtor list } \\
\text { - obligation to repay subsidy if conditions of a previous subsidy } \\
\text { have not been fulfilled }\end{array}$ \\
\hline $\begin{array}{l}\text { In the case of subsidy drawn down } \\
\text { in respect of specific child }\end{array}$ & $\begin{array}{l}\text { - any subsidy drawn down earlier must be repaid or no subsidy } \\
\text { may be requested for the child } \\
\text { - the applicant may choose the more favourable option } \\
\text { (effective: Government Decree No } 46 / 2019 \text { (III. 12.)) }\end{array}$ \\
\hline $\begin{array}{l}\text { Precondition for applying for } \\
\text { subsidy in respect of an anticipated } \\
\text { child }\end{array}$ & $\begin{array}{l}\text { - the child anticipated under the subsidy received by the } \\
\text { applicant prior to HPS must be born by the time the HPS } \\
\text { application is submitted }\end{array}$ \\
\hline $\begin{array}{l}\text { Deadline for the birth of the } \\
\text { anticipated child }\end{array}$ & $\begin{array}{l}\text { - } 4 \text { years in the case of } 1 \text { child } \\
\text { - } 8 \text { years in the case of } 2 \text { children } \\
\text { - } 10 \text { years in the case of } 3 \text { children (this option is only available } \\
\text { for new property) }\end{array}$ \\
\hline $\begin{array}{l}\text { Sanction for unborn children or for } \\
\text { fewer children than anticipated }\end{array}$ & $\begin{array}{l}\text { - the amount drawn down unlawfully must be repaid together } \\
\text { with the default interest specified in the Civil Code } \\
\text { - if the applicant committed to having three children, the subsidy } \\
\text { must be repaid with fivefold interest }\end{array}$ \\
\hline Maximum property price limit & $\begin{array}{l}\text { - no limit for new property } \\
\text { - HUF } 35 \text { million in the case of used property (repealed by: } \\
\text { Government Decree No } 46 / 2019 \text { (III. 12.)) }\end{array}$ \\
\hline $\begin{array}{l}\text { Maximum ownership interest in } \\
\text { existing property }\end{array}$ & $\begin{array}{l}\text { - no restriction for new property } \\
\text { - min. } 50 \text { per cent in the case of used property (repealed by: } \\
\text { Government Decree No } 26 / 2018 \text { (II. 28.)) }\end{array}$ \\
\hline $\begin{array}{l}\text { Use of proceeds from sale of } \\
\text { property purchased with previous } \\
\text { subsidy }\end{array}$ & $\begin{array}{l}\text { - no restriction for new property } \\
\text { - in the case of used property, the proceeds from the property } \\
\text { sold within } 5 \text { years } \\
\text { must be reinvested in the property purchased with the current } \\
\text { subsidy (repealed: Government Decree No } 26 / 2018 \text { (II. 28.)) }\end{array}$ \\
\hline $\begin{array}{l}\text { Mandatory stay in the subsidised } \\
\text { property }\end{array}$ & $\begin{array}{l}\text { - minimum } 10 \text { years residence, only for the owners and the } \\
\text { subsidised persons } \\
\text { - it may be registered as the registered office of the owner } \\
\text { (effective: Government Decree No } 152 / 2019 \text { (VI. 26.)) }\end{array}$ \\
\hline
\end{tabular}

Source: Based on Government Decrees 16/2016 (II. 10.) and 17/2016 (II. 10.), and their amendments. 
Although the level of the subsidy has not changed since its announcement, the subsidy for the favoured small regions - and the high subsidy amount meant to foster the realisation of the complex objective - had a favourable impact on those wishing to move to such locations (Table 3).

\begin{tabular}{|c|c|c|}
\hline & \multicolumn{2}{|c|}{ SUBSIDY RATE } \\
\hline $\begin{array}{l}\text { In the case of non-favoured } \\
\text { small regions }\end{array}$ & New property & Used property \\
\hline for 1 child & HUF 0.6 million & HUF 0.6 million \\
\hline for 2 children & HUF 2.6 million & HUF 1.43 million \\
\hline for 3 children & HUF 10 million & HUF 2.2 million \\
\hline for 4 or more children & HUF 10 million & HUF 2.75 million \\
\hline $\begin{array}{l}\text { In the case of favoured } \\
\text { small regions }\end{array}$ & \multicolumn{2}{|c|}{$\begin{array}{l}\text { - with a complex objective, it corresponds to the subsidy applicable for } \\
\text { new property } \\
\text { with a specific objective, } 50 \text { per cent of the subsidy applicable to new } \\
\text { property }\end{array}$} \\
\hline $\begin{array}{l}\text { In the case of a subsidy } \\
\text { already claimed in respect } \\
\text { of a specific child }\end{array}$ & \multicolumn{2}{|c|}{$\begin{array}{l}\text { - the subsidy claimed earlier must be repaid or no subsidy may be } \\
\text { requested for the child } \\
\text { - from the options above, the one more favourable for the applicant may } \\
\text { be chosen (effective: Government Decree No } 46 / 2019 \text { (III. 12.)) }\end{array}$} \\
\hline $\begin{array}{l}\text { Subsidy for children } \\
\text { subsequently born }\end{array}$ & \multicolumn{2}{|c|}{$\begin{array}{l}\text { - in the case of used property, HUF } 0.4 \text { million for each child } \\
\text { - no extra subsidy in the case of new property }\end{array}$} \\
\hline Subsidised loan & \multicolumn{2}{|c|}{$\begin{array}{l}\text { - HUF } 10 \text { million for new property and } 3 \text { children } \\
\text { - HUF } 10 \text { million for new property and } 2 \text { children (effective: Government } \\
\text { Decree No 209/2018 (XI. 13.)) } \\
\text { - used property: for } 3 \text { children: HUF } 15 \text { million and for } 2 \text { children: HUF } 10 \\
\text { million children (effective: Government Decree No } 46 / 2019 \text { (III. 12.)) }\end{array}$} \\
\hline
\end{tabular}

Source: Based on Government Decrees 16/2016 (II. 10.) and 17/2016 (II. 10.), and their amendments

\section{Data and methodology}

Purposes of the analysis: to provide a comprehensive overview of families that benefited from HPS-based subsidies and the effect this had on the number of existing and anticipated children and type of property purchased; to assess the childbearing willingness of these families; to identify the similarities and differences in applicant groups based on the relationship between income and property value. Secondary information was processed within the context of laws and technical articles on housing subsidies.

Using a credit institution database covering the period 2016-2020, we performed the analysis using anonymous data of 625 households who have benefited from the housing subsidy in the regions of western Hungary, Central Transdanubia, and central Hungary. The relevant information for the analysis from the database 
includes the time of the subsidy drawdown, the number of anticipated children, and subsidised property type and location. Information related to the family's disposable income, the market value of the purchased property, and the existence of previous property is available only in the case of those applicants who took a loan as well ( 391 households). In this paper, the segmentation of the families by size always includes the number of existing and anticipated children.

This study provides a general characterisation of HPS beneficiaries based on the number of children, propensity to have children, and the type of property purchased with the subsidy. A cluster analysis was used to group the population of those applying for a loan in addition to the non-refundable HPS, based on the relationship between family income and property value. The measurement scales of the variables are the same, but their value range differs significantly. This prompted standardisation before the procedure. Since cluster analysis is sensitive to outliers, we excluded cases that distort modelling, resulting in 371 applicants being analysed. The "best solution" is elusive in the clustering procedure (Obádovics 2009); accordingly, we performed the hierarchic cluster analysis using several procedures (centroid, cluster average, and Ward's method). The centroid method returned the cluster with the highest number of unique features. Based on the hierarchic cluster analysis, we estimated the number of distinct groups to be between five and eight. Following the hierarchic method, we finally accepted seven cluster results based on the K-means clustering procedure. The lower, five cluster solutions were rejected, as three groups comprised 91 per cent of the total population. While the key objective of the analysis was to identify unique characteristics, the cluster characteristics could not be precisely defined due to the high number of elements. In the case of more than seven clusters, there were also clusters with a single element, and thus these solutions were also rejected.

\section{Analysis of HPS beneficiaries}

\subsection{Overview of national data among HPS applicants}

According to the analyses prepared by the Mária Kopp Institute for Demography and Families (KINCS), almost 170,000 people applied for the subsidy by the end of 2020 (KINCS 2019, 2020b; Papházi et al. 2021). Ninety per cent of the beneficiaries of the non-refundable subsidy already had at least one child when applying for the subsidy: 15 per cent of them had one child, 47 per cent had two children, and 38 per cent had or planned to have three or more children, also taking anticipated children into account. The ratio of large families among HPS beneficiaries is several times higher than the ratio of large families in Hungary (8 per cent). More than a third of the applicants plan to have additional children (59 per cent have one, 39 per cent have two and 2 per cent have three). The highest childbearing willingness is among those who will become two-child families once the anticipated child is factored in (58 per cent), and 38 per cent among those agreeing to have three children (KINCS 2019). Furthermore, 14.9 per cent of the applicants were only motivated 
to have additional children due to the subsidy's incentive effect (KINCS 2020a). In terms of property type, the purchase of used property tends to dominate both the applicants who anticipate having children (69.2 per cent) and the applicants already with a child or children (68 per cent), with the higher propensity to have children associated with used property (KINCS 2019).

According to the Hungarian Central Statistical Office (HCSO) database, the positive impact of the subsidy on the number of children is not detectable from 2016 to 2019. Although 3.3 per cent more children were born in 2020 compared to the previous year, this still falls short of the 2016 figure (HCSO 2021b).

Several papers have addressed the positive impact of the subsidy on the number of children born. Based on these studies, the HPS may still improve childbearing willingness in the future, but the success of family policy in this respect strongly depends on living standards as well as other moral and ethical norms (Sági- Lentner 2020; Tatay et al. 2019).

The average amount of the disbursed subsidy is HUF 2.4 million (HUF 5.2 million for the purchase of new property, HUF 2.4 million for the purchase of used property). 78 per cent of the subsidised amount is linked to new property and 2 per cent to the expansion of existing real estate. Between 2016 and 2019, one in six property purchases (44 per cent of new properties and 12 per cent of used properties) relied on the HPS (HCSO 2021a; KINCS 2019).

According to the Magyar Nemzeti Bank's (the Central Bank of Hungary, MNB) November 2020 Housing Market Report, subsidised borrowing has experienced steady growth; however, a decline in the financing of both new and used properties occurred from the second half of 2020. This decline may be attributable to the uncertainty caused by the coronavirus pandemic. According to the data, 77 per cent of applicants for the non-refundable subsidy supplement the subsidy with a loan. Until the end of June 2020, 134,000 people applied for HPS loans totalling HUF 400 billion (MNB 2020).

The emergence of HPS caused increased real estate demand, which led to soaring property prices that consumed almost 75 per cent of the subsidy disbursement amounts (Banai et al. 2019), thereby further complicating the housing opportunities of young couples (Elek - Szikra 2018).

According to the research of Sági et al. (2017), the social perception of the subsidy is positive, as more than 60 per cent of the respondents believe the subsidy will help them buy a home. This is also confirmed by the research of KINCS (2020a, b), and Tóth - Horváthné (2018). Although individual family policy measures may improve young people's propensity to have children, other factors, some of which have a greater effect than housing conditions, also influence childbearing willingness. Some of these factors include overall quality of life, a stable economy, employment and partnership, inflation, unemployment, income factors, health, 
religion, ethnicity, moral standards, and the lingering effects of the communist past. This is particularly true for couples who are extremely uncertain about having children. Targeted housing policy decisions have little influence on many of the abovementioned factors (Kapitány - Spéder 2018; Spéder et al. 2017; Sági - Lentner 2020; Szikra 2016; HCSO 2016).

\subsection{Analysis of the beneficiaries of non-refundable HPS}

Among the regions, the West Transdanubia region has the highest net income per capita and the lowest unemployment rate. In terms of GDP per capita specified at a regional level, 44 per cent of GDP is generated by the three examined regions (HCSO 2018a, 2020a, 2020b). With the exception of 2020, the number of housing subsidy applications is steadily rising (Figure 1). The decline experienced in 2020 is attributable to the uncertainty caused by the pandemic and was not restricted to these regions, but occurred nationwide. This effect appears to be slightly stronger in the western part of the country as pandemic measures partially restricted the movement of Hungarians working in Austria.

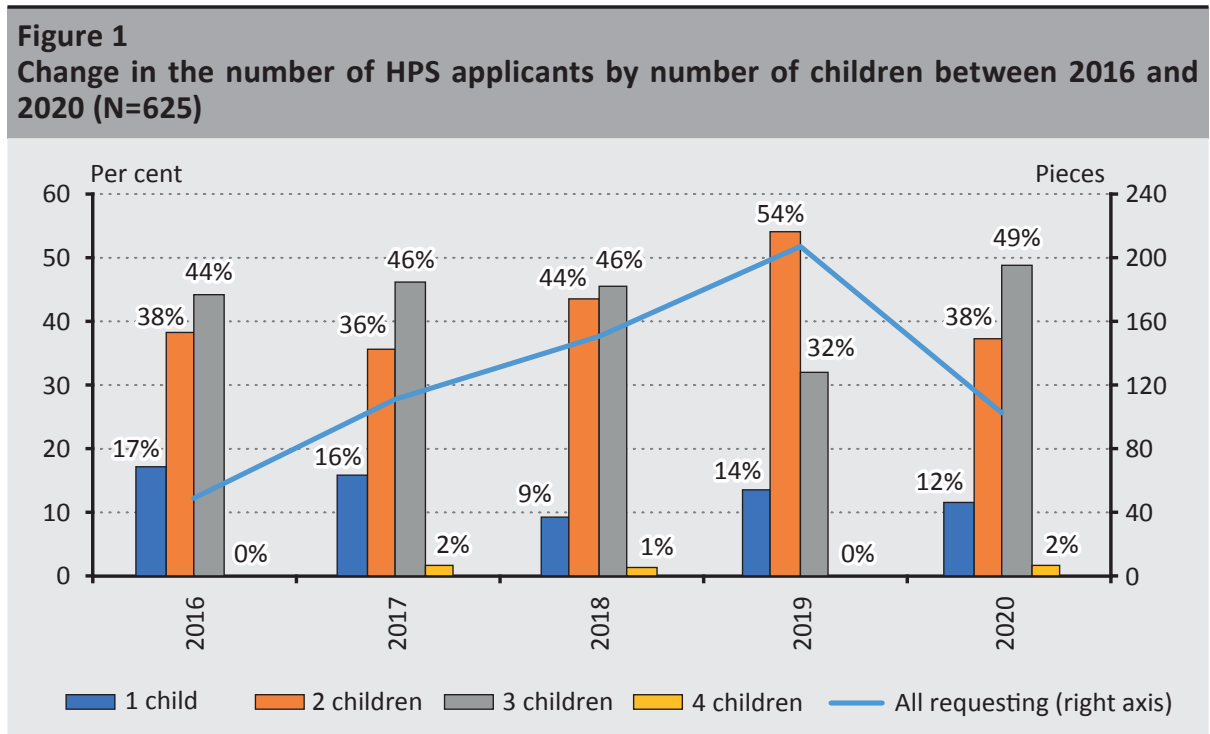

The greatest demand for the housing subsidy occurred in 2019. The factor driving the demand was likely the interest-subsidised loans that became available to twochild families. This indicates that a decrease in interest payable has a favourable impact on the property market. The distorting effects of the state interest subsidy reduce the borrower's exposure to increased interest servicing triggered by potential negative cyclical developments (Kiss - Vadas 2006). Of the total number of applicants, 234 families (37 per cent) only used the non-refundable subsidy, while 63 per cent of the applicants supplemented the state subsidy with a loan. 
Regarding the number of children, 44 per cent of the applications were submitted under a two-child family model (including existing and anticipated children) (Table 4). Families wishing to have three children comprised 43 per cent. The ratio of families with one child was a mere 13 per cent.

\section{Table 4}

Distribution of HPS applicants in the period 2016-2020 based on the number of children and the number of anticipated children

\begin{tabular}{|c|c|c|c|c|c|c|c|c|c|c|c|}
\hline & \multicolumn{2}{|c|}{$\begin{array}{c}\text { One-child } \\
\text { family model }\end{array}$} & \multicolumn{4}{|c|}{ Two-child family model } & \multicolumn{5}{|c|}{ Three-child family model } \\
\hline & \multicolumn{11}{|c|}{ children } \\
\hline & total & existing & total & existing & $\begin{array}{c}1 \text { antici- } \\
\text { pated }\end{array}$ & $\begin{array}{c}2 \text { antici- } \\
\text { pated }\end{array}$ & total & existing & $\begin{array}{c}1 \text { antici- } \\
\text { pated }\end{array}$ & $\begin{array}{c}2 \text { antici- } \\
\text { pated }\end{array}$ & $\begin{array}{c}3 \text { antici- } \\
\text { pated }\end{array}$ \\
\hline Applicants (number) & 81 & 81 & 277 & 178 & 51 & 48 & 267 & 221 & 26 & 17 & 3 \\
\hline $\begin{array}{l}\text { Without taking } \\
\text { a loan (number) }\end{array}$ & 74 & 74 & 114 & 109 & 5 & 0 & 46 & 40 & 3 & 2 & 1 \\
\hline $\begin{array}{l}\text { Also taking } \\
\text { subsidised and/or } \\
\text { market-based loan } \\
\text { (number) }\end{array}$ & 7 & 7 & 163 & 69 & 46 & 48 & 221 & 181 & 23 & 15 & 2 \\
\hline
\end{tabular}

Of those who took advantage of the subsidy, 32 per cent did so for one child, 49 per cent for two children, and only 19 per cent for three children. Only two per cent of one-child families took on a loan. This is likely due to the low subsidy amount and the lack of interest-subsidised credit (Horváthné Kökény - Tóth 2017). Large families represent the highest ratio (57 per cent), which is attributable to the availability of the interest-subsidised loans throughout the programme. Nationally, 36 per cent of families have one child, 22 per cent have two, 6 per cent have three, and 2 per cent have four or more children. Among HPS beneficiaries, the ratio of families with two children is several times higher than the national sample and even higher for families with three children (HCSO 2012a). According to the national data of the HCSO, childless (32 per cent) and two-child families (30 per cent) account for the largest ratio of residential mortgage borrowers. These are followed by families with one child (26 per cent). Large families represent the lowest percentage (12 per cent) of borrowers (HCSO 2018b), which is the opposite of the distribution by number of children among the HPS beneficiaries.

The government also intends to use the programme to foster the attainment of demographic objectives, i.e. to increase the number of births. HPS applicants can best contribute to this by having children in addition to the ones they have already planned. Only 23 per cent of state subsidy beneficiaries make an advance commitment to having children (Table 4), which falls short of the national childbearing willingness rate of 33 per cent (KINCS 2019). A total of 68 per cent of those agreeing in advance wish to have two children, while 32 per cent intend to 
have three children in the future. Seventy-seven per cent of the applicants apply for the subsidy after bearing children. Those who anticipate having children are considered to have contributed to population growth only if they have committed to having a child they had not previously planned to have before the subsidy, rather than just bringing forward their previously planned childbearing. The highest childbearing willingness ( 36 per cent) is among the applicants who intend to have up to two children (including the anticipated child). Seventeen per cent of families committed to having three children promise to increase their number of children to three by the statutory deadline. By the end of 2020, 62 per cent of all those anticipating further children had fulfilled their commitment, i.e. they bore a child they had committed to having. Only one applicant who took the subsidy in 2016 was unable to fulfil the childbearing commitment by the deadline date. If a young couple fail to fulfil their commitment to having children, or fulfil it only partially (with the exception of confirmed health reasons), the used subsidy amount must be repaid to the state together with the default interest, plus five times the penalty interest if they committed to having three or more children. This is how the government intends to prevent unfounded commitments to having children, which would only be designed to claim the higher subsidy amounts.

Forty-five per cent of all applicants who committed to having children in the future plan to have two more children (12 per cent plan to have a second and third child, accounting for 2 per cent of all applicants) and 2 per cent commit to having a third child (Table 5). The rest of them plan to have one more child.

\begin{tabular}{|c|c|c|}
\hline $\begin{array}{l}\text { Table } 5 \\
\text { Ratio of two-child } \\
\text { those anticipating }\end{array}$ & $\begin{array}{l}\text { and large families commi } \\
\text { children in future }\end{array}$ & additional children w \\
\hline & & $\begin{array}{l}\text { Childbearing willingness } \\
\qquad(\mathrm{N}=135)\end{array}$ \\
\hline & $\begin{array}{l}\text { anticipates } 1 \text { child } \\
\text { (second child) }\end{array}$ & $35 \%$ \\
\hline  & $\begin{array}{l}\text { anticipates } 2 \text { children } \\
\text { (first and second child) }\end{array}$ & $33 \%$ \\
\hline & $\begin{array}{l}\text { anticipates } 1 \text { child } \\
\text { (second child) }\end{array}$ & $18 \%$ \\
\hline Large family & $\begin{array}{l}\text { anticipates } 2 \text { children } \\
\text { (second and third child) }\end{array}$ & $12 \%$ \\
\hline & $\begin{array}{l}\text { anticipates } 3 \text { children } \\
\text { (first, second and third child) }\end{array}$ & $2 \%$ \\
\hline Total number of appl & cants making advance comm & \\
\hline Total number of & anticipating 1 child & $53 \%$ \\
\hline applicants making & anticipating 2 children & $45 \%$ \\
\hline commitment & anticipating 3 children & $2 \%$ \\
\hline
\end{tabular}


The positive changes in the subsidy conditions that appeared in 2019 are reflected in the number of applications and in the increase in the number of applicants who supplement the subsidy with a loan (Table 6).

\begin{tabular}{|c|c|c|c|c|c|}
\hline \multicolumn{6}{|c|}{$\begin{array}{l}\text { Table } 6 \\
\text { Drawdown of HPS by family size and year of application }\end{array}$} \\
\hline & \multicolumn{2}{|c|}{ Large family } & \multicolumn{2}{|c|}{ Normal-sized family } & \multirow{2}{*}{ Total (no.) } \\
\hline & without a loan & with loan & without a loan & with loan & \\
\hline 2016 (no.) & 10 & 13 & 20 & 9 & 52 \\
\hline New properties & \multicolumn{2}{|c|}{$74 \%$} & \multicolumn{2}{|c|}{$45 \%$} & 30 \\
\hline Used properties & \multicolumn{2}{|c|}{$26 \%$} & \multicolumn{2}{|c|}{$55 \%$} & 22 \\
\hline 2017 (no.) & 16 & 38 & 50 & 8 & 112 \\
\hline New properties & \multicolumn{2}{|c|}{$41 \%$} & \multicolumn{2}{|c|}{$76 \%$} & 66 \\
\hline Used properties & \multicolumn{2}{|c|}{$59 \%$} & \multicolumn{2}{|c|}{$24 \%$} & 46 \\
\hline 2018 (no.) & 12 & 59 & 52 & 28 & 151 \\
\hline New properties & \multicolumn{2}{|c|}{$34 \%$} & \multicolumn{2}{|c|}{$38 \%$} & 54 \\
\hline Used properties & \multicolumn{2}{|c|}{$66 \%$} & \multicolumn{2}{|c|}{$63 \%$} & 97 \\
\hline 2019 (no.) & 2 & 64 & 44 & 96 & 206 \\
\hline New properties & \multicolumn{2}{|c|}{$33 \%$} & \multicolumn{2}{|c|}{$58 \%$} & 103 \\
\hline Used properties & \multicolumn{2}{|c|}{$67 \%$} & \multicolumn{2}{|c|}{$42 \%$} & 103 \\
\hline 2020 (no.) & 6 & 47 & 22 & 29 & 104 \\
\hline New properties & \multicolumn{2}{|c|}{$51 \%$} & \multicolumn{2}{|c|}{$41 \%$} & 48 \\
\hline Used properties & \multicolumn{2}{|c|}{$49 \%$} & \multicolumn{2}{|c|}{$59 \%$} & 56 \\
\hline Total (no.) & 46 & 221 & 188 & 170 & 625 \\
\hline
\end{tabular}

The ratio of used properties increased for both family models over the years. In 2019, there was a further increase in demand for used properties among large families, and a moderate decrease among those committed to the two-child family model. We assume these changes are attributable to the fact that since the beginning of 2019, the subsidised loan for new properties has become available to families with two children and, since the middle of the year, for the purchase of used property as well, which inspired large families to consider the subsidy. Overall, 58 per cent of large families and 47 per cent of normal-sized families purchased used property with the aid of the subsidy.

Following the abolition of the HUF 35 million maximum property price limit for used properties, 40 per cent of the properties above this limit are now used properties. Overall, however, the volume of high-value property purchases has 
not increased, and the stock of used and new properties exceeding HUF 35 million shows a downward trend compared to the period before and after 2019.

Prior to 2018, subsidy applicants with an existing property could not apply for HPS to purchase used property while simultaneously keeping an existing property. This provision was cancelled in 2018. Subsequently, more than 90 per cent of those who applied for an HPS subsidy with an existing property used the direct HPS to purchase used property; the ratio of these applicants declined to 61 per cent in 2019. Also considering the propensity to have children, we found that only 2 per cent of those who committed to having children in advance used the subsidy to buy another property in addition to their existing one.

Property purchases in the favoured small regions are below 5 per cent in the sample; accordingly, the effect of the subsidies is not reflected in any growth in the sample element numbers. This may be due to the low number of subsidised small regions in the regions under review, while their level of development exceeds the national average.

Forty-eight per cent of those applying for a direct subsidy use the funds to finance new property (a total of HUF 1.5 billion, HUF 5 million/property on average), fortyfive per cent to finance the purchase of used property (a total of HUF 485 million, HUF 1.7 million/property on average), and 7 per cent to finance expansion work on existing real estate (a total of HUF 67 million, HUF 1.5 million/property on average) (Figure 2). The distribution by child in the case of new property purchases is 15 per cent (HUF 26 million in total, HUF 0.6 million/property), 48 per cent (HUF 377 million in total, HUF 2.6 million/property) and 37 per cent (HUF 1 billion in total, HUF 10 million/property), respectively. In the case of purchasing used property, these figures are 13, 35 and 52 per cent, respectively. Three quarters of the subsidies are disbursed for investment in new property. Half of the disbursed subsidies is concentrated at 18 per cent of the eligible applicants (14 per cent without those committing to having children in advance), due to the fact that these applicants are large families and thus receive a non-refundable state subsidy of HUF 10 million for the purchase of new property. Families with two children, who comprise 23 per cent of all applicants purchasing new property, receive less than 20 per cent of the disbursements, even though they represent a large number of new property purchase transactions. The reason for this is that the state provides a subsidy of HUF 2.6 million to help with the purchase in their case. 


\section{Figure 2}

Number of applicants for direct HPS and their share in the disbursed subsidy amount by number of children and property type $(\mathrm{N}=625)$

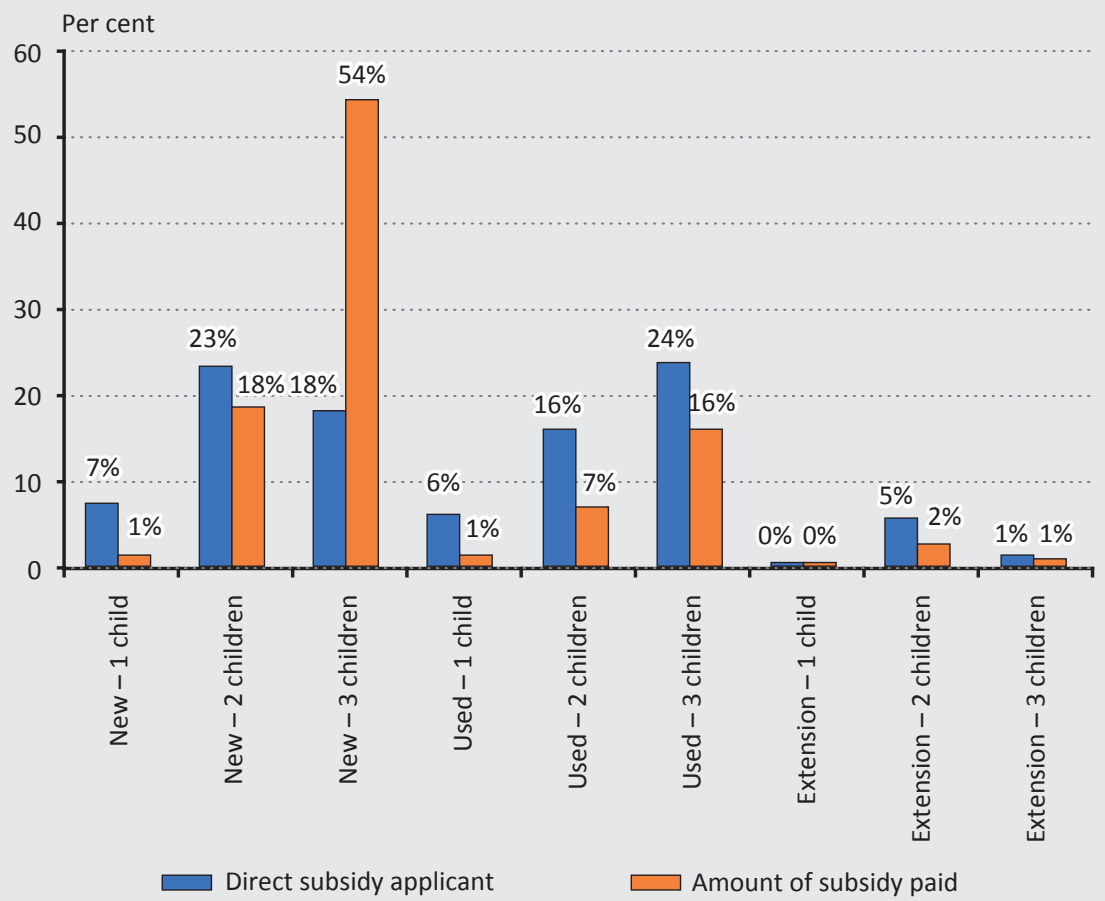

Those making advance commitments to having children (anticipators) receive 24 per cent of the subsidies (HUF 495 million). From this group, 55 per cent buy new property and 39 per cent buy used property, while 6 per cent use the funds to expand their existing house with additions. Fifty-seven per cent of the anticipators with 2 children (including the anticipated child) and 52 per cent of anticipators with three children (including the anticipated child) use the subsidy to purchase new property. The distribution of both family models is almost identical among those investing in new property and making an advance commitment to having children. However, there is a significant difference in disbursed subsidy amounts, to the benefit of large families. The amount of the subsidy realised by those who become large families via an advance commitment is 48 per cent of the amount disbursed to all anticipators. In the case of families with two children, the figure is 30 per cent. The number of families becoming families with three children did not increase in excess of the families becoming two-child families as a result of the advance commitment, despite the high incentive of the HUF 10 million subsidy applicable 
to new properties. Fourteen per cent of large family applicants use the subsidy to buy a new property and already have three children at the time of the application.

\subsection{Classification of applicants by income and property price depending on family size}

We obtained income data for 391 households. After eliminating the outliers, we analysed 371 families. A higher proportion of the borrowers ( 57 per cent) were large families. Seventy-two per cent of normal-sized families realise their first-time homebuying objectives below a property price of HUF 35 million (Figure 3). Eleven per cent of two-child families and 5 per cent of large families (including the anticipated child), purchase a property with a value that exceeds HUF 50 million.

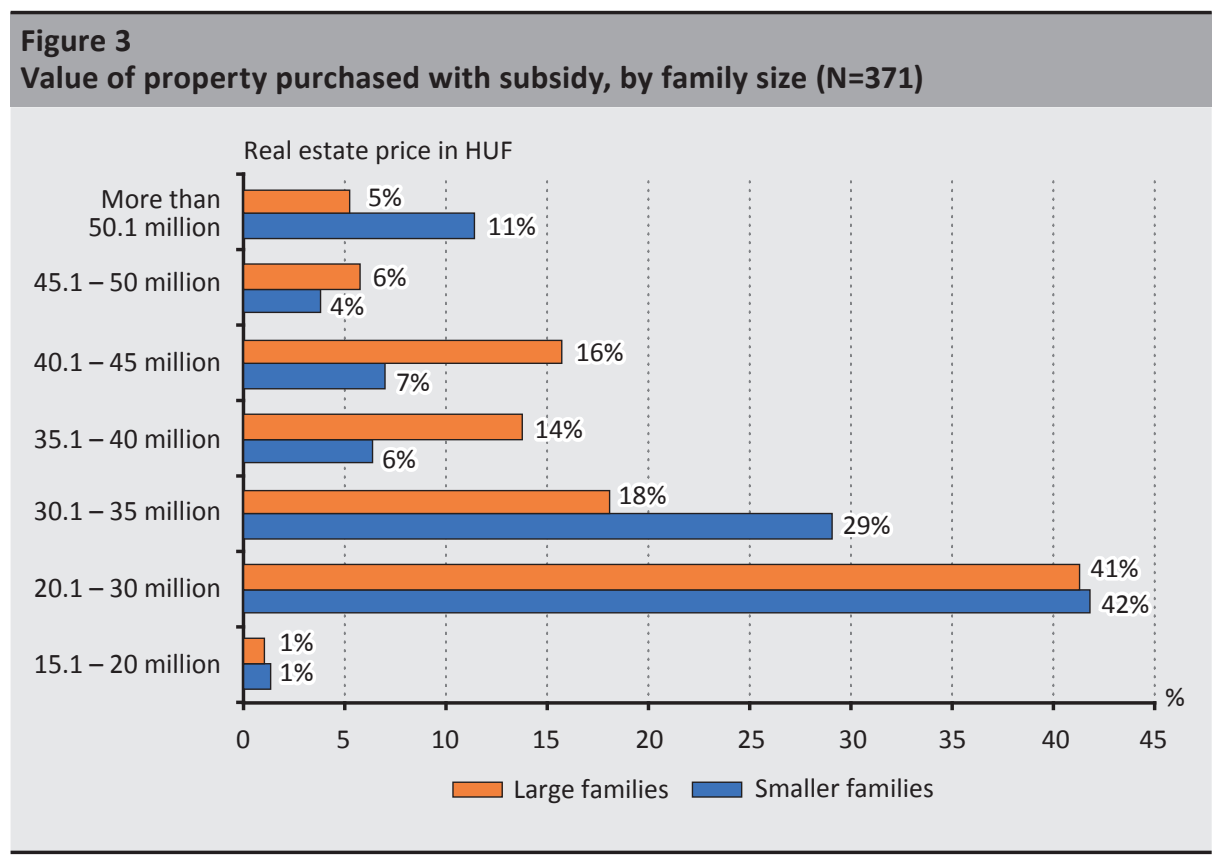

Normal-sized families usually buy new property with a smaller floor area (Table 7). The same applies to 60 per cent of large families who tend to buy slightly larger used properties because the family is larger. 


\begin{tabular}{|c|c|c|c|c|c|c|}
\hline \multicolumn{7}{|l|}{$\begin{array}{l}\text { Table } 7 \\
\text { Distribu }\end{array}$} \\
\hline \multirow[b]{2}{*}{$\begin{array}{l}\text { Property } \\
\text { floor area }\end{array}$} & \multicolumn{3}{|c|}{ Normal-sized family } & \multicolumn{3}{|c|}{ Large family } \\
\hline & $\begin{array}{c}\text { New } \\
\text { property }\end{array}$ & $\begin{array}{c}\text { Used } \\
\text { property }\end{array}$ & $\begin{array}{l}\text { Distribution of } \\
\text { properties owned } \\
\text { by normal-sized } \\
\text { families by floor } \\
\text { area }\end{array}$ & $\begin{array}{c}\text { New } \\
\text { property }\end{array}$ & $\begin{array}{c}\text { Used } \\
\text { property }\end{array}$ & $\begin{array}{c}\text { Distribution of } \\
\text { properties owned } \\
\text { by large families by } \\
\text { floor area }\end{array}$ \\
\hline under $60 \mathrm{~m}^{2}$ & $16 \%$ & $4 \%$ & $10 \%$ & $3 \%$ & $5 \%$ & $4 \%$ \\
\hline $61-70 \mathrm{~m}^{2}$ & $5 \%$ & $4 \%$ & $4 \%$ & $12 \%$ & $4 \%$ & $7 \%$ \\
\hline $71-80 \mathrm{~m}^{2}$ & $15 \%$ & $30 \%$ & $22 \%$ & $24 \%$ & $15 \%$ & $18 \%$ \\
\hline $81-90 \mathrm{~m}^{2}$ & $11 \%$ & $23 \%$ & $17 \%$ & $14 \%$ & $16 \%$ & $15 \%$ \\
\hline $91-100 \mathrm{~m}^{2}$ & $15 \%$ & $12 \%$ & $13 \%$ & $35 \%$ & $15 \%$ & $22 \%$ \\
\hline $101-110 \mathrm{~m}^{2}$ & $4 \%$ & $9 \%$ & $6 \%$ & $4 \%$ & $7 \%$ & $6 \%$ \\
\hline $111-120 \mathrm{~m}^{2}$ & $5 \%$ & $4 \%$ & $4 \%$ & $0 \%$ & $8 \%$ & $5 \%$ \\
\hline $121-140 \mathrm{~m}^{2}$ & $4 \%$ & $3 \%$ & $3 \%$ & $3 \%$ & $9 \%$ & $7 \%$ \\
\hline above $141 \mathrm{~m}^{2}$ & $27 \%$ & $12 \%$ & $19 \%$ & $6 \%$ & $21 \%$ & $16 \%$ \\
\hline \multicolumn{7}{|c|}{ Total investment in new and used property relative to family size } \\
\hline $\begin{array}{c}\text { Property } \\
\text { investments }\end{array}$ & $52 \%$ & $48 \%$ & & $37 \%$ & $63 \%$ & \\
\hline
\end{tabular}

Nationwide, 32 per cent of privately owned properties have a floor area below 60 $\mathrm{m}^{2}$. Due to the statutory requirements, the property size cannot be below $60 \mathrm{~m}^{2}$ in the case of HPS applicants. Forty-three per cent of the total Hungarian population lives in properties $60-100 \mathrm{~m}^{2}$ in size. The ratio of properties exceeding this size is almost 35 per cent among HPS applicants, while it is 25 per cent nationally. The data show that the HPS increased the floor area of the property purchased (HCSO 2012b).

When dividing the family income into five income groups with an identical number of elements, we found that among those with loans, the ratio of large families (57 per cent) exceeds that of normal-sized families. This is because in income band 3 and above, their ratio exceeds (and to the largest degree in income band 4) that of the normal-sized families (Table 8). 


\begin{tabular}{|c|c|c|c|c|c|c|}
\hline \multicolumn{7}{|c|}{$\begin{array}{l}\text { Table } 8 \\
\text { Distribution of those who took a loan in addition to HPS, by income category, family } \\
\text { size and childbearing willingness }\end{array}$} \\
\hline \multirow[b]{2}{*}{$\begin{array}{c}\text { Family income } \\
\text { band }\end{array}$} & \multicolumn{3}{|c|}{ Normal-sized family } & \multicolumn{3}{|c|}{ Large family } \\
\hline & $\begin{array}{l}\text { Normal-sized } \\
\quad \text { family } \\
\text { applicants as } \\
\text { percentage of } \\
\text { all applicants }\end{array}$ & $\begin{array}{c}\text { Families } \\
\text { committing to } \\
\text { having children } \\
\text { as percentage } \\
\text { of normal- } \\
\text { sized family } \\
\text { applicants }\end{array}$ & $\begin{array}{c}\text { Families } \\
\text { committing to } \\
\text { having children } \\
\text { in advance as } \\
\text { percentage of } \\
\text { anticipators }\end{array}$ & $\begin{array}{l}\text { Large family } \\
\text { applicants as } \\
\text { percentage of } \\
\text { all applicants }\end{array}$ & $\begin{array}{c}\text { Families } \\
\text { committing to } \\
\text { having children } \\
\text { as percentage } \\
\text { of large family } \\
\text { applicants }\end{array}$ & $\begin{array}{c}\text { Families } \\
\text { committing to } \\
\text { having children } \\
\text { in advance as } \\
\text { percentage of } \\
\text { anticipators }\end{array}$ \\
\hline $\begin{array}{l}\text { Band 1: HUF } \\
0-418,000\end{array}$ & $53 \%$ & $64 \%$ & $81 \%$ & $47 \%$ & $17 \%$ & $19 \%$ \\
\hline $\begin{array}{l}\text { Band 2: HUF } \\
419,000-487,000\end{array}$ & $53 \%$ & $63 \%$ & $83 \%$ & $47 \%$ & $14 \%$ & $17 \%$ \\
\hline $\begin{array}{l}\text { Band 3: HUF } \\
488,000-607,000\end{array}$ & $39 \%$ & $68 \%$ & $61 \%$ & $61 \%$ & $27 \%$ & $39 \%$ \\
\hline $\begin{array}{l}\text { Band 4: HUF } \\
608,000-760,000\end{array}$ & $27 \%$ & $50 \%$ & $50 \%$ & $73 \%$ & $19 \%$ & $50 \%$ \\
\hline $\begin{array}{l}\text { Band 5: HUF } \\
761,000-\end{array}$ & $43 \%$ & $38 \%$ & $67 \%$ & $57 \%$ & $14 \%$ & $33 \%$ \\
\hline $\begin{array}{l}\text { Total applicants } \\
\text { with a loan }\end{array}$ & $43 \%$ & $57 \%$ & $70 \%$ & $57 \%$ & $18 \%$ & $30 \%$ \\
\hline
\end{tabular}

Those committed to the two-child family model aim to buy a home with more moderate family income. One reason for this is the higher net income available through the tax allowance for larger families, as well as the family allowance and child-care/infant-care benefit, which are included in the family income. Eighty-two per cent of three-child families already had their children when they submitted their applications. The same applies to 43 per cent of two-child families. Those making an advance commitment to having children usually belong to the lower income groups, and 62 per cent of these purchase cheaper property, i.e. HUF 35 million with a useful floor area below $80 \mathrm{~m}^{2}$. This suggests that the subsidy makes it possible for those from lower income groups to buy their own home.

The government gives priority support to families with three children for the purchase of new homes. However, the households surveyed in the western region are dominated by households with two children or those who become two-child families by having an additional child, generally by acquiring new property. Contrary to our expectations, large families (with a child anticipated in the future) tend to buy used property. A smaller proportion agreed to have an additional child in order to become large families, and the number of people who have another two children in addition to an existing child is low. 
Seventy-eight per cent of applicants declared that they did not own a residential property when they applied for the subsidy. Fourteen per cent did, but sold it to improve the family's housing conditions by using the subsidies (Table 9).

Only 8 per cent of the applicants (77 per cent of these are large families) kept their previous home and bought an additional property using the subsidies. These families belong to the top three income brackets. Few of these families were able to draw the direct subsidy of HUF 10 million, since merely 24 per cent of the property transactions were for new property, and of these, not all buyers were large families.

\begin{tabular}{|c|c|c|c|c|c|c|}
\hline \multicolumn{7}{|c|}{$\begin{array}{l}\text { Table } 9 \\
\text { Distribution of applicants by family size and incor } \\
\text { a subsidised property transaction occurred in additior }\end{array}$} \\
\hline \multirow[t]{2}{*}{ 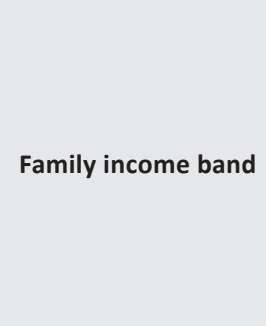 } & \multicolumn{3}{|c|}{$\begin{array}{c}\text { No existing property, or it is sold and } \\
\text { reinvested }\end{array}$} & \multicolumn{3}{|c|}{ Existing property retained } \\
\hline & $\begin{array}{l}\text { Normal-sized } \\
\text { family }\end{array}$ & Large family & $\begin{array}{l}\text { Distribution of } \\
\text { applicants } \\
\text { without } \\
\text { existing } \\
\text { property as } \\
\text { percentage of } \\
\text { all applicants }\end{array}$ & $\begin{array}{l}\text { Normal-sized } \\
\text { family }\end{array}$ & Large family & $\begin{array}{l}\text { Distribution of } \\
\text { applicants } \\
\text { retaining their } \\
\text { existing } \\
\text { property as } \\
\text { percentage of } \\
\text { all applicants }\end{array}$ \\
\hline $\begin{array}{l}\text { Band 1: } \\
\text { HUF 0-418,000 }\end{array}$ & $53 \%$ & $47 \%$ & $100 \%$ & $0 \%$ & $0 \%$ & $0 \%$ \\
\hline $\begin{array}{l}\text { Band 2: } \\
\text { HUF 419,000-487,000 }\end{array}$ & $53 \%$ & $47 \%$ & $100 \%$ & $0 \%$ & $0 \%$ & $0 \%$ \\
\hline $\begin{array}{l}\text { Band 3: } \\
\text { HUF 488,000-607,000 }\end{array}$ & $39 \%$ & $61 \%$ & $99 \%$ & $0 \%$ & $100 \%$ & $1 \%$ \\
\hline $\begin{array}{l}\text { Band 4: } \\
\text { HUF 608,000-760,000 }\end{array}$ & $27 \%$ & $73 \%$ & $84 \%$ & $25 \%$ & $75 \%$ & $16 \%$ \\
\hline $\begin{array}{l}\text { Band 5: } \\
\text { HUF 761,000- }\end{array}$ & $48 \%$ & $52 \%$ & $77 \%$ & $24 \%$ & $76 \%$ & $23 \%$ \\
\hline $\begin{array}{l}\text { Total applicants with } \\
\text { a loan }\end{array}$ & $45 \%$ & $55 \%$ & $92 \%$ & $23 \%$ & $77 \%$ & $8 \%$ \\
\hline
\end{tabular}

Based on applicant family income and the market value of the property purchased using the subsidy, we created seven distinct groups using cluster analysis. The three largest groups concentrate 83 per cent of the elements in the analysed sample. Based on the variance values and the distance between the clusters, the sevencluster solution also shows the highest similarity within the group. 
Our analysis aimed to discover which social groups the subsidy provides essential assistance for in achieving housing objectives, and at what income level and property value it encourages the purchase of a second home.

\section{Figure 4 \\ Grouping of subsidy applicants by family income and property price}

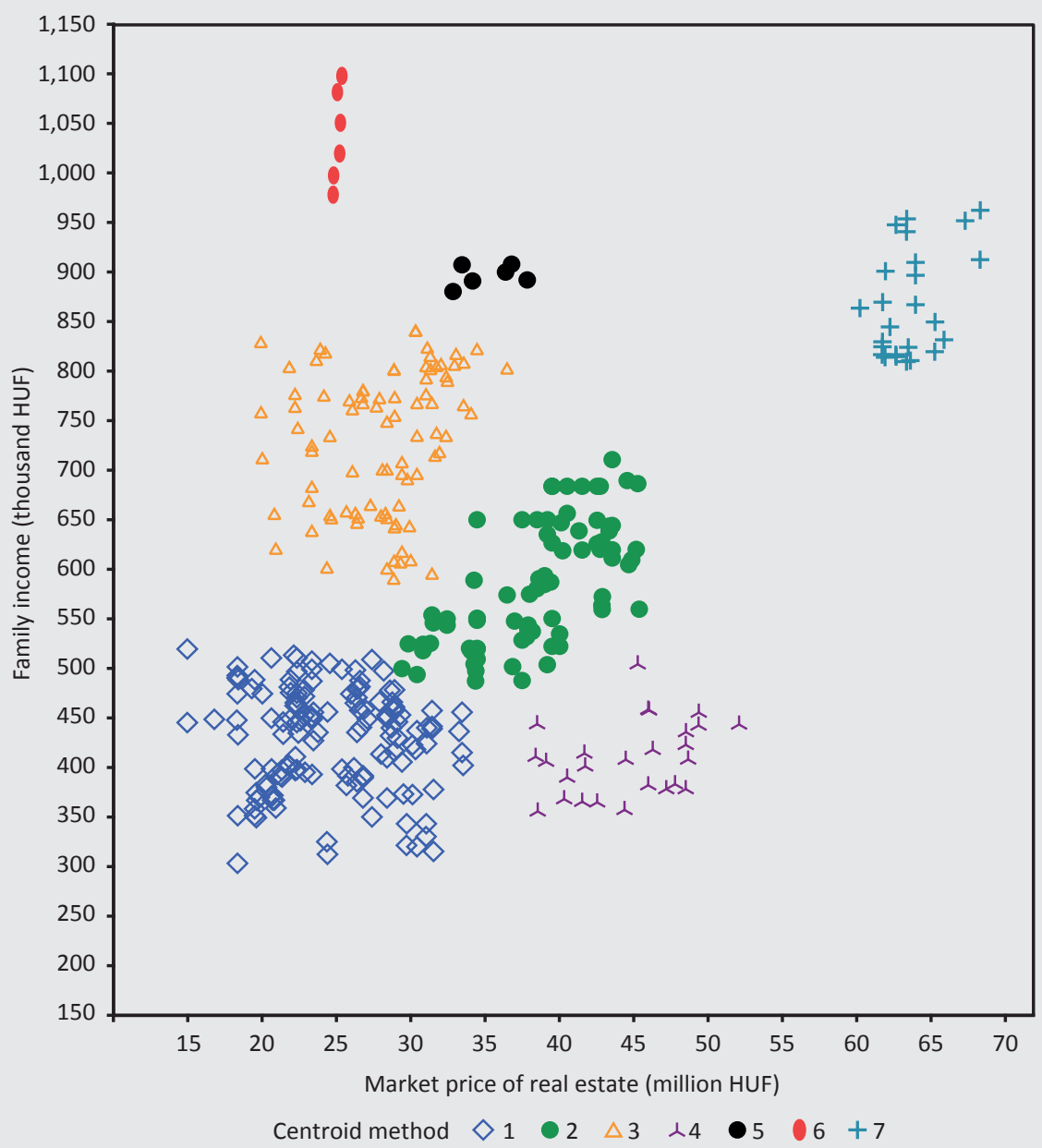

Note: The analysed data were edited in SPSS 
Group 1 has the highest population with a share of 38 per cent (Table 10). This group also owns the cheapest properties, with an average price of HUF 26 million (Figure 4 ), and has the lowest income (HUF 429,000). Accordingly, this group relies on the subsidy to buy a first property. Group 1 has the highest number of families with two children (52 per cent). Similar to Group 4, Group 1 also has high childbearing willingness ( 42 per cent), which may have been partly induced by the acquisition of property due to the low-income level (Table 10).

\section{Table 10}

Share of the individual groups and their composition based on family size, advance commitment to having children and existing property

\begin{tabular}{|c|c|c|c|c|c|}
\hline & $\begin{array}{l}\text { Number of } \\
\text { group } \\
\text { members } \\
\text { (units) }\end{array}$ & $\begin{array}{c}\text { Share of the } \\
\text { group }\end{array}$ & $\begin{array}{l}\text { Distribution by } \\
\text { family model } \\
\text { relative to the } \\
\text { group }\end{array}$ & $\begin{array}{l}\text { Childbearing } \\
\text { willingness } \\
\text { within the } \\
\text { group }\end{array}$ & $\begin{array}{l}\text { Has an existing } \\
\text { property and } \\
\text { retains it } \\
\text { (units) }\end{array}$ \\
\hline Group 1 & 142 & \multirow{3}{*}{$38 \%$} & & $42 \%$ & 0 \\
\hline Large family & 68 & & $48 \%$ & $18 \%$ & 0 \\
\hline Normal-size family & 74 & & $52 \%$ & $64 \%$ & 0 \\
\hline Group 2 & 79 & \multirow{3}{*}{$21 \%$} & & $38 \%$ & 9 \\
\hline Large family & 56 & & $71 \%$ & $23 \%$ & 9 \\
\hline Normal-sized family & 23 & & $29 \%$ & $74 \%$ & 0 \\
\hline Group 3 & 87 & \multirow{3}{*}{$23 \%$} & & $18 \%$ & 15 \\
\hline Large family & 57 & & $66 \%$ & $7 \%$ & 10 \\
\hline Normal-sized family & 30 & & $34 \%$ & $40 \%$ & 5 \\
\hline Group 4 & 26 & \multirow{3}{*}{$7 \%$} & & $54 \%$ & 0 \\
\hline Large family & 14 & & $54 \%$ & $36 \%$ & 0 \\
\hline Normal-sized family & 12 & & $46 \%$ & $75 \%$ & 0 \\
\hline Group 5 & 6 & \multirow{3}{*}{$2 \%$} & & $0 \%$ & 6 \\
\hline Large family & 4 & & $67 \%$ & $0 \%$ & 4 \\
\hline Normal-sized family & 2 & & $33 \%$ & $0 \%$ & 2 \\
\hline Group 6 & 6 & \multirow{3}{*}{2} & & $33 \%$ & 0 \\
\hline Large family & 3 & & $50 \%$ & $33 \%$ & 0 \\
\hline Normal-sized family & 3 & & $50 \%$ & $33 \%$ & 0 \\
\hline Group 7 & 25 & \multirow{3}{*}{$7 \%$} & & $36 \%$ & 0 \\
\hline Large family & 10 & & $40 \%$ & $40 \%$ & 0 \\
\hline Normal-sized family & 15 & & $60 \%$ & $33 \%$ & 0 \\
\hline
\end{tabular}

It is evident that families with lower incomes are more likely to commit to having additional children. Over 70 per cent of the households used the subsidy to purchase a used property (Table 11). This also contributes to the fact that this moderateincome group benefits the least from the direct state subsidy of HUF 10 million 
(15 per cent), since the share of new property is minimal for family houses and only 41 per cent for flats. More than half of the new property purchases (54 per cent) are made in villages (Table 11) due to the lower real estate prices. This group is in great need of the subsidy, as even with the subsidy they can only afford the most modest of homes. The amount of direct non-refundable state subsidy per capita is HUF 3.1 million, which is the second lowest value compared to the other groups.

Table 11

Groups by property characteristics

\begin{tabular}{l|c|c|c|c|c|c|c} 
& Group 1 & Group 2 & Group 3 & Group 4 & Group 5 & Group 6 & Group 7 \\
\hline
\end{tabular}

Distribution by settlement type and property type and quality (per cent, units)

\begin{tabular}{l|c|c|c|c|c|c|c}
\hline VILLAGE & $49 \%$ & $18 \%$ & $62 \%$ & $50 \%$ & $50 \%$ & $50 \%$ & $12 \%$ \\
\hline used (units) & 47 & 4 & 28 & 9 & 3 & 2 & 3 \\
\hline new (units) & 23 & 10 & 16 & 4 & 0 & 1 & 0 \\
\hline TOWN & $51 \%$ & $82 \%$ & $38 \%$ & $50 \%$ & $50 \%$ & $50 \%$ & $88 \%$ \\
\hline used (units) & 52 & 43 & 13 & 0 & 3 & 1 & 3 \\
\hline new (units) & 20 & 22 & 20 & 13 & 0 & 2 & 19 \\
\hline
\end{tabular}

Distribution by useful floor area (per cent)

\begin{tabular}{l|c|c|c|c|c|c|c}
\hline below $60 \mathrm{~m}^{2}$ & $9 \%$ & $8 \%$ & $7 \%$ & $0 \%$ & $0 \%$ & 0 & $0 \%$ \\
\hline $61-70 \mathrm{~m}^{2}$ & $8 \%$ & $1 \%$ & $10 \%$ & $0 \%$ & $0 \%$ & 0 & $0 \%$ \\
\hline $71-80 \mathrm{~m}^{2}$ & $30 \%$ & $1 \%$ & $26 \%$ & $0 \%$ & $17 \%$ & 6 & $0 \%$ \\
\hline $81-90 \mathrm{~m}^{2}$ & $26 \%$ & $11 \%$ & $11 \%$ & $0 \%$ & $0 \%$ & 0 & $12 \%$ \\
\hline $91-100 \mathrm{~m}^{2}$ & $18 \%$ & $15 \%$ & $26 \%$ & $12 \%$ & $50 \%$ & 0 & $4 \%$ \\
\hline $101-110 \mathrm{~m}^{2}$ & $3 \%$ & $18 \%$ & $2 \%$ & $12 \%$ & $0 \%$ & 0 & $0 \%$ \\
\hline $111-120 \mathrm{~m}^{2}$ & $2 \%$ & $10 \%$ & $3 \%$ & $15 \%$ & $0 \%$ & 0 & $0 \%$ \\
\hline $121-140 \mathrm{~m}^{2}$ & $0 \%$ & $10 \%$ & $5 \%$ & $19 \%$ & $0 \%$ & 0 & $8 \%$ \\
\hline above $141 \mathrm{~m}^{2}$ & $4 \%$ & $25 \%$ & $8 \%$ & $42 \%$ & $33 \%$ & 0 & $76 \%$ \\
\hline
\end{tabular}

Group 2 has a share of 21 per cent and is the group with the third highest population (Table 10). This group has the highest proportion of large families (71 per cent). With an average monthly family income of HUF 580,000, applicants in this group buy property at around HUF 40 million as their first property (Figure 4). These typically belong to the categories over $90-110 \mathrm{~m}^{2}$, but the distribution of larger properties 
is also even (Table 11). Eleven per cent of families in this group have an existing residential property (Table 10). They have the third highest childbearing willingness (following Groups 4 and 1). Fifty-four per cent of applicants opted for used houses in urban areas (Table 11). As in Groups 3 and 4, the ratio of those with two loans is high (53 per cent) here as well. On average, they agree to a market-based loan of HUF 14 million, in addition to the subsidised loan, which is the highest loan value of all groups. Twenty per cent of the group members are able to take advantage of the HUF 10 million direct subsidy, as they typically look for used houses in urban areas. In this group, the amount of direct non-refundable state subsidy per capita is HUF 3.5 million. This is the third lowest value when compared to the other groups.

Families in this group are considered to be in the mid-range both in terms of income and property, and they undertake higher indebtedness for a house in an urban area (their income situations permit this). Thirty-eight per cent of applicants buy new houses (Table 11), while in Group 4, 36 per cent of families purchase used homes. The main difference between the two groups is that Group 2 buys smaller houses and flats in urban areas under higher income conditions and higher indebtedness, while those in Group 4 purchase new and bigger property in rural areas. These groups clearly reflect the additional costs incurred in towns compared to villages.

Twenty-three per cent of applicants belong to Group 3 (Table 10). Large families comprise 66 per cent of this group, which is the second most populous group for large families. Families in this group have higher income than those in the mid-range and buy cheaper $90-100 \mathrm{~m}^{2}$ houses and $60-80 \mathrm{~m}^{2}$ flats (Table 11). Fifty-two per cent of the applicants in this group also take out market-based loans - in addition to the subsidised loans - with an average amount of HUF 7.5 million.

Group 3 has the highest share of rural properties (62 per cent), resulting in a decrease in the ratio of new properties (Table 11). The families moving to villages are motivated to buy used property, while newly built flats are the more popular choice in urban areas. Seventeen per cent of the applicants in this group own or have owned real estate and do not use the subsidy to buy their very first home (Table 10). With a stable livelihood, this group has the highest number of applicants (33 per cent) and receive the highest direct subsidy of HUF 10 million. However, in return, many (18 per cent) tend not to commit to having additional children. The amount of the direct non-refundable state subsidy per capita in this group is HUF 4.7 million, which is the highest amount compared to the other categories even though Group 3 does not have the lowest income.

Group 4 includes 7 per cent of the applicant families (Table 10), who - under lowincome level conditions - buy properties of above average value at HUF 46 million, which is high compared to their income level (Figure 4). Half of those in Group 4 make an advance commitment to having children (54 per cent), which is the highest 
commitment to childbearing among all groups. This may be positively influenced by the difference between income and the value of the property to be purchased. The average indebtedness over the amount of the subsidised loan is HUF 8.3 million. Forty-six per cent of the families in this group hold two loans.

Almost all applicants in Group 4 buy a family house, and all those with two children buy new property (Table 11). As is the case with Group 7, families in Group 4 also tend to buy new property. Due to their income position, almost half of the applicants (46 per cent) opt to move to a village to secure a spacious home for the family. The properties purchased are over $90 \mathrm{~m}^{2}$, but a good number of the applicants (35 per cent) own properties with floor space over $151 \mathrm{~m}^{2}$ (Table 11). Only 19 per cent of this group are able to draw the highest subsidy amount of HUF 10 million. The amount of the direct non-refundable state subsidy per capita in Group 4 is HUF 3.8 million, which is the third highest value compared to the other groups.

With Group 4, it may be assumed that the commitment in advance to having children was partly motivated by the acquisition of property, as higher childbearing willingness is accompanied by low income and high-value property. However, despite the high number of large families, only a few were able to take advantage of the HUF 10 million subsidy. In our view, these families would have not been able to buy a higher value property without the subsidy - they did not own a property before, as the mortgage burden of property is significant even with the high property price. This group reflects the highest tendency to make an advance commitment to having children. Nevertheless, this group does not receive the highest subsidy amount, even though their income situation would justify it.

Group 5 includes only a few families, merely 2 per cent of borrowers (Table 10). Each member of this group, which mostly comprises large families (67 per cent), belong to the highest income category. They usually purchase used houses with useful floor areas of 90-100 $\mathrm{m}^{2}$ or over $141 \mathrm{~m}^{2}$ (Table 11) as second properties (Table 11) (only one applicant replaced their home with a higher quality home) at an average price of HUF 37 million (Figure 4).

People in this group already owned a home at the time of application, which they retained despite purchasing the subsidised property (Table 10). In addition to the direct subsidy, they also make full use of the subsidised loan. Families with two children (50 per cent) were not yet eligible for the subsidised loan at the time of the application, and thus they took a market-based loan. None of the members in this group commits to having additional children. In this group, the amount of direct non-refundable state subsidy per capita is HUF 1.9 million, which is the lowest compared to the other groups. Families in Group 5 maximise the use of the subsidy, and with minimal additional debt they increase their living standards with 
the additional property, all without committing to having more children. Due to the existing property they already owned, these families would have not been able to benefit from this allowance in 2016 and 2017.

At 2 per cent, Group 6 consists of the smallest portion of applicants (Table 10). Within this group, the distribution by family size is even, with 33 per cent committing to having additional children. All families utilised the maximum amount of the direct state subsidy and drew down the subsidised loan, without supplementing it with additional market-based loans. The properties purchased by this group include flats below HUF 30 million, with a useful floor area of 70-80 $\mathrm{m}^{2}$ (Table 11). The applicants declared that they had not previously owned a property, although they have the highest disposable family income in the examined sample (Table 10). Indeed, in their case, income of HUF 1 million (Figure 4) is accompanied by properties of the lowest value, all of which are flats (Table 11). In this group, the amount of direct non-refundable state subsidy per capita is HUF 4.6 million, which is the second highest value compared to the individual categories.

We believe this property could be more of a second home purchase, for which the available state subsidy offered a good opportunity, thereby increasing the already stable living conditions of these families. Their favourable financial circumstances, the use of the subsidy elements, and the lack of other loans indicate that they did not necessarily need the subsidy to finance the property transaction. However, without the subsidy, these households might not have embarked on a property investment. This group well reflects the property incentive effect of the subsidy, but it is unlikely to generate additional childbearing.

Seven per cent of families belong to Group 7 (Table 10). They buy large properties that cost over HUF 65 million and are in a high-income bracket (HUF 867,000 on average) (Figure 4). Applicants who already owned property sold it and used the proceeds to purchase new property. The ratio of large families is the lowest in this group (40 per cent), while childbearing willingness is 36 per cent. All but one of the applicants were already eligible for subsidised loans, which they used to the maximum extent. In this group, the amount of direct non-refundable state subsidy per capita is HUF 3.7 million, which is the fourth highest value compared to the other groups. The extension of the subsidised loan to families with two children created a very favourable opportunity for the members of this group. This is evidenced by the fact that all but one of the two-child families embarked on the property purchase trail after the subsidised loan became available. This significantly reduced their exposure to market-based loans, and thereby their debt servicing. This group of purchased properties includes larger flats $\left(80 \mathrm{~m}^{2}\right)$, while 48 per cent of the family houses have a useful floor area over $171 \mathrm{~m}^{2}$ (Table 11). Sixteen per cent of the applicants were eligible for the highest non-refundable state subsidy of HUF 10 million, which was not accompanied by an advance commitment to 
having children as a positive effect. This group contains the highest number of urban inhabitants ( 88 per cent) and the number of those purchasing new property is high as well (Table 11).

Based on our analysis, we named and characterised the individual groups of applicants as follows (Figure 4):

1) Needy small families buying used flats - lowest income - cheapest property price - no high commitment to having children

2) Buyers of urban used houses, large families - medium income - medium property price - high advance commitment to having children

3) Upper-middle class large families - benefiting from the HUF 10 million subsidy - medium to high income - more modest property - low propensity to have additional children

4) Buyers of new houses in villages - lower income - high property prices - highest advance commitment to having children

5) House buyers for investment, in addition to an existing property - high income - medium property price - without committing to having additional children

6) Investment property buyers - high income - low property price - without committing to having additional children

7) Small families living in new, luxury urban flats - high income - highest property price - without committing to having additional children

\section{Summary and conclusions}

Our study, conducted for the western and central regions of Hungary using an anonymous credit institution database, found that 44 per cent of those applying for a subsidy chose the two-child family model, and 43 per cent the large family model. Childbearing willingness is 23 per cent, i.e. slightly lower than the national rate of 33 per cent, but there is no significant difference in the number of children committed to in advance, nor the preferred family size. In the regions surveyed, 68 per cent of those who made an advance commitment to having children opted for the two-child family model. Childbearing willingness is of great importance, since there is a possibility of agreeing to have more children than originally planned, thereby supporting the realisation of the government's demographic objectives. More than half of those committing to giving birth to a child in the future agree to have one more child. The number of those committing to three children is minimal, at only 2 per cent. 
Seventeen per cent of those buying a new property and making an advance commitment to having children would like to become a large family, while 38 per cent aim for a two-child family. Those committing to having children - opting for the large family or two-child family model - tend to buy new and used property from the subsidy in an almost in equal share, i.e. half and half. This implies that the high subsidy - HUF 10 million - has not been a significant incentive for families to become large families or to invest in a new property. The childbearing willingness was supported to a greater degree by the existence of the subsidy. This finding is supported by the fact that at the national level the rate of childbearing willingness is almost the same among those opting for new and used property. The government's demographic objectives are least supported by the large families (14 per cent) that do not commit to having additional children and use the subsidy for buying new property.

The absence of an income cap for subsidy drawdowns encouraged 8 per cent of the applicants to buy a second property. The number of these applicants could be reduced by the reintroduction and comprehensive application (extending it to new properties) of the restrictions on property ownership in excess of 50 per cent, which had been enforced until 2019. In this regard, we agree with the proposal of Banai et al. (2019) and suggest it would be advisable to revise the eligibility criteria in this respect.

We identified seven distinct groups based on property values and family income. The analysis shows that Group 1 combines the lowest income and property price, under high childbearing willingness. A high quality, new property is unaffordable for families in this group. Consequently, we considered families in this group to be most in need of a subsidy to purchase a home. Group 1 benefits from a small share of the disbursed subsidies, despite the fact that, on a social basis, families grouped here need the most support. The availability of the HUF 10 million subsidy does not generally improve the situation for families in Group 1 because the benefits extended for smaller family sizes and used property purchases are limited.

The childbearing willingness is higher in the lower income groups (1, 2 and 4). These groups are also more likely to draw smaller subsidies, move to the agglomeration or villages, and show a higher interest in family houses. Group 3 received the highest state subsidy despite their medium to high income level. We identified three groups $(5,6$ and 7$)$ for whom the state subsidy is not a matter of necessity, but often only a means for purchasing an additional property to add to their existing one, which places them in an even more advantageous position compared to other applicants.

However, an undisputed advantage of the subsidy scheme is the support for families and the purchase of used property. Support for large families has been a priority in all previous housing support schemes, but it has never been of this magnitude 
before. Accordingly, in the future we aim to analyse how many of the applicants who made an advance commitment to having children have indeed been encouraged to have additional children.

Given the economic stimulus and employment creation effect of the subsidy and the strong interest in it, efforts should be made to ensure its long-term sustainability since it contributes to the predictability of housing investment for families. To this end, consideration should be given to harmonising the subsidy amounts depending on the number of children, with the exclusion of the possibility of the accumulation of properties, and introducing an income cap. Providing housing subsidies to ensure that housing policy objectives meet the expectations related to higher birth rates is not enough. A stable and favourable macroeconomic environment must be continued to provide. Accordingly, we clearly confirm previous research findings that emphasise the predictability and purposefulness of family policy support.

\section{References}

Banai, Á.- Pankov, D. - Fábián, G. - Nagy, T. (2019): Hogyan alakitotta át a CSOK a hazai lakás- és hitelpiacot? (How has HPS transformed the Hungarian housing and credit market?). Szakmai cikk (Special article), Magyar Nemzeti Bank.

Beaujouan, E. - Sobotka, T. - Brzozowska, Zs. - Zeman, K. (2017): Has childlessness peaked in Europe? Population \& Societies, No. 540(January): 1-4.

Békés, G. - Horváth, Á. - Sápi, Z. (2016): Lakóingatlanárak és települési különbségek (Differences between residential property prices and settlements). Közgazdasági Szemle (Economic Review), No 63 (December) 1289-1323. http://dx.doi.org/10.18414/ KSZ.2016.12.1289

Bényei, Z. (2011): Javaslat a lakásfenntartást segítő támogatások átalakítására (Proposal for the reform of subsidies for the maintenance costs of housing). Kapocs, 10(2): pp. 1-25

Csermák, K. (2011): Quo Vadis, magyar lakáspolitika? (Quo Vadis, Hungarian housing policy?). Polgári Szemle (Civic Review Journal of Economic and Social Sciences), 7(1): pp. 43-62.

Dániel, Zs. (1997): Lakástámogatás és társadalmi újraelosztás (Housing subsidy and social redistribution). Közgazdasági Szemle (Economic Review), No 44(October): pp. 848-877.

Dániel, Zs. (2004): Állam és piac - lakástámogatás, lakásfinanszírozás, reformok. Nemzetközi tapasztalatok (State and market - housing subsidies, finance of housing and reforms. International experiences). Közgazdasági Szemle (Economic Review), No 51(February): pp. 139-152. 
Dorbritz, J. - Ruckdeschel, K. (2007): Kinderlosigkeit in Deutschland. Ein europäischer Sonderweg? Daten, Trends und Gründe. In: Konietzka, D. - Kreyenfeld, M. (Eds.): Ein Leben ohne Kinder. VS Verlag für Sozialwissenschaften, Wiesbaden, pp. 45-81. https:// doi.org/10.1007/978-3-531-90323-1_2

Elek, Zs. - Szikra, D. (2018): Fordított újraelosztás a lakáspolitikában: a CSOK versengő céljai (Reverse redistribution in housing policy: competing HPS objectives). Új Egyenlőség. (New Equality) https://ujegyenloseg.hu/forditott-ujraelosztas-a-lakaspolitikaban-a-csokversengo-celjai/. Downloaded: 16 May 2020.

Fitoussi, J.P. - Sen, A. - Stiglitz, E.J. (2008): Report by the Commission on the Measurement of Economic Performance and Social Progress. Chapter 2: 1-292. https://ec.europa.eu/ eurostat/documents/8131721/8131772/Stiglitz-Sen-Fitoussi-Commission-report.pdf. Downloaded: 9 February 2021.

Hegedűs, J. (2006): Lakáspolitika és lakáspiac, a közpolitika korlátai (Housing policy and housing market, the limits of public policy). Magyar Valóság (Hungarian Reality), 2006(5): pp. 1-36.

Horváthné Kökény, A. - Tóth, F. (2017): A családok otthonteremtési kedvezménye a családok szemszögéböl (Home purchase subsidy for families from the families' point of view). Gradus, 4(2): pp. 528-533.

Kapitány, B. - Spéder, Zs. (2018): Gyermekvállalás (Childbearing willingness). In: Monostori, J. - Őri, P. - Spéder, Zs. (ed.): Demográfiai Portré 2018. Jelentés a magyar népesség helyzetéról (Demographic Portrait of Hungary, 2018. Report on the conditions of the Hungarian population). HCSO Hungarian Demographic Research Institute, Budapest, pp. 47-64.

Kiss, G. - Vadas, G. (2006): A lakáspiac szerepe a monetáris transzmisszióban (The Role of the Housing Market in Monetary Transmission). Közgazdasági Szemle (Economic Review), 53(May): 408-427.

KINCS (2019): Családi Otthonteremtési Kedvezmény (CSOK) szerződéseinek elemzése a 2016-2017-2018. évi adatok alapján (Analysis of contracts under the Home Purchase Subsidy (HPS) for Families based on the 2016-2017-2018 data). Mária Kopp Institute for Demography and Families (KINCS), Budapest, pp. 1-75. https://www.koppmariaintezet. hu/docs/CSOK2_vegso1.0_honlap_form.pdf. Downloaded: 19 April 2021.

KINCS (2020a): Családi Otthonteremtési Kedvezmény igénybevétele 2019 július és 2020 június között elemzés (Drawdown of Home Purchase Subsidy between July 2019 and June 2020). Office of Research, Office of Policy Analysis, Mária Kopp Institute for Demography and Families (KINCS), Budapest, pp. 1-10. https://www.koppmariaintezet.hu/docs/ CSOK_2019jul_2020jun_KINCS.pdf. Downloaded: 9 February 2021. 
KINCS (2020b): Egy éves a Családvédelmi Akcióterv (One year of the Family Protection Action Plan) 1 July 2020. Mária Kopp Institute for Demography and Families (KINCS), Budapest, pp. 1-16. https://www.koppmariaintezet.hu/docs/1eves_a_Csaladvedelmi_Akcioterv_ Sajtotajekoztato.pdf. Downloaded: 9 February 2021.

Kováts, B. (2007): Az önkormányzati hatáskörbe került lakhatási támogatások vizsgálata 31 önkormányzat példáján (Analysis of housing subsidies under local government competence based on the example of 31 local governments). Habitat for Humanity Magyarország. https://www.habitat.hu/files/Onkormanyzati_lakhatasi_tamogatasok_Habitat_0720.pdf. Downloaded: 23 July 2020.

HCSO (2012a): A családok családösszetétel és a gyermekek száma szerint (Families by family composition and number of children). Hungarian Central Statistical Office. http://www. ksh.hu/nepszamlalas/tablak_haztartas. Downloaded: 24 May 2021.

HCSO (2012b): A lakott lakások tulajdonjelleg, alapterület, épitési év és településtípus szerint, 2011 (Occupied homes by type of ownership, floor area, year of construction and settlement type, 2011). Hungarian Central Statistical Office. https://www.ksh.hu/ nepszamlalas/tablak_lakasviszonyok. Downloaded: 24 May 2021.

HCSO (2016): Lakáshelyzet és gyermekvállalás: fontos, de nem a legfontosabb. A CSOK termékenységi hatásairól (Housing condition and childbearing willingness: important, but not the most important. About the effects of HPS on fertility). Demografia.hu/Korfa, 16(1): 1-4. https://www.demografia.hu/kiadvanyokonline/index.php/korfa/article/view/2652

HCSO (2018a): Fejlettségi szint (Maturity level) (2003-2018). Hungarian Central Statistical Office. https://www.ksh.hu/thm/1/indi1_1_4.html. Downloaded: 24 May 2021.

HCSO (2018b): Lakossági lakáshitelezés, 2017 (Retail housing loans, 2017). KSH Statisztikai Tükör (HCSO Statistical Review) Hungarian Central Statistical Office, 13 April. https://www. ksh.hu/docs/hun/xftp/idoszaki/lakashitel/lakashitel1712.pdf. Downloaded: 24 May 2021.

HCSO (2020a): Egy före jutó bruttó és nettó jövedelem régió és településtípus szerint (Gross and net income per capita by region and settlement type). Hungarian Central Statistical Office. http://www.ksh.hu/stadat_files/jov/hu/jov0045.html. Downloaded: 24 May 2021.

HCSO (2020b): Munkanélküliségi ráta (Unemployment rate). Hungarian Central Statistical Office. https://www.ksh.hu/docs/hun/xstadat/xstadat_evkozi/e_qlf027h.html. Downloaded: 24 May 2021.

HCSO (2021a): Lakossági lakáshitelezés, 2020. I. félév (Retail housing loans, 2020 H1). Hungarian Central Statistical Office. http://www.ksh.hu/docs/hun/xftp/idoszaki/ lakashitel/20201/index.html. Downloaded: 24 April 2021.

HCSO (2021b): A népesség, népmozgalom föbb mutatói (Key indicators of the population and demographic changes). Hungarian Central Statistical Office. http://www.ksh.hu/ stadat_files/nep/hu/nep0001.html. Downloaded: 24 April 2021. 
Levi, M. (1993): The Construction of Consent. Administration, Compliance and Governability Program, Australian National University, Canberra.

Lesthaeghe, R. (2011): The "second demographic transition": a conceptual map for the understanding of late modern demographic developments in fertility and family formation. Historical Social Research, 36(2): 179-218. https://doi.org/10.12759/hsr.36.2011.2.179218

Mayo, S. K. - Angel, S. (1993): Housing: Enabling Markets to Work. A World Bank Policy, Washington, D.C., pp. 1-167. https://documents1.worldbank.org/curated/ en/387041468345854972/pdf/multiOpage.pdf. Downloaded: 6 November 2020

Mádi, L. (2008): Lakáspolitika - otthonteremtés: Történések és tapasztalatok a közelmúlt magyarországi időszakából. (Housing policy - home creation: Events and experiences from the recent period in Hungary). Ph.D. thesis, University of West Hungary. http://www. nyme.hu/fileadmin/dokumentumok/ktk/Kepzes_doktori/2008/2008_MadiLaszlo_d.pdf. Downloaded: 1 February 2020.

Mádi, L. (2017): Egy kívánatos és reális lakáspolitikai körvonalai Magyarországon 2017-ben (An Optimal and a Real Housing Policy in Hungary in 2017). Acta Wekerleensis, 2017(1): $1-20$.

Maleque, M. (2019): For us, family is also first. Budapest Demographic Summit. https:// csalad.hu/tamogatasok/zahid-maleque-for-us-family-is-also-first. Downloaded: 10 January 2021.

MNB (2020): Housing Market Report, November 2020. Magyar Nemzeti Bank. https://www. mnb.hu/letoltes/lakaspiaci-jelentes-2020-november-en.pdf. Downloaded: 13 February 2021.

Neyer, G. - Thévenon, O. - Monfardini, C. (2016): Policies for Families: Is there a Best Practice? Families and Societies. European Policy Brief, pp. 1-12. http://www.familiesandsocieties. eu/wp-content/uploads/2016/12/policy_brief_5.pdf. Downloaded: 5 September 2020.

Novák, K. (2020): A magyar családpolitikának kettős célja van (Hungarian housing policy has a dual purpose). https://csalad.hu/tamogatasok/a-magyar-csaladpolitikanak-kettos-celjavan. Downloaded: 10 January 2021

Obádovics, Cs. (2009): Klaszteranalízis (Cluster analysis). Eszterházy Károly Főiskola, Eger.

Papházi, T. - Fail, Á. - Horváth-Varga, A. (2021): A Családi Otthonteremtési Kedvezmény 2020. évi eredményei (Results of the Home Purchase Subsidy in 2020). Flash report, Mária Kopp Institute for Demography and Families (KINCS), Budapest, pp. 1-16. https://www. koppmariaintezet.hu/docs/CSOK_2020_gyorsjelentes_2021_03_05.pdf. Downloaded: 16 April 2021. 
Rothstein B. (1998): Just Institutions Matter. The Moral and Political Logic of the Universal Welfare State. Cambridge University Press, Cambridge, pp. 1-254. https://doi. org/10.2307/2585870

Sági, J. - Tatay, T. - Lentner, Cs. - Neumanné, I.V. (2017): A család- és otthonteremtési adókedvezmények, illetve támogatások egyes hatásai (Certain Effects of Family and Home Setup Tax Benefits and Subsidies). Pénzügyi Szemle (Public Finance Quarterly), 2017(2): pp. 173-189.

Sági, J. - Lentner, Cs. (2020): A magyar népességpolitikai intézkedések tényezői és várható hatásai (Factors and expected effects of the Hungarian population policy measures). Közgazdasági Szemle (Economic Review), 67(March): 289-308. https://doi.org/10.18414/ KSZ.2020.3.289

Singhammer, J. (2019): A family gives you a home and boosts the abilities of children. Budapest Demographic Summit. https://csalad.hu/tamogatasok/johannes-singhammera-family-gives-you-a-home-and-boosts-the-abilities-of-children. Downloaded: 10 January 2021.

Sobotka, T. (2017): Childlessness in Europe: Reconstructing Long-Term Trends Among Women Born in 1900-1972. In: Kreyenfeld, M. - Konietzka, D. (eds.): Childlessness in Europe. Contexts, Causes, and Consequences, Demographic Research Monographs, pp. 17-53. https://doi.org/10.1007/978-3-319-44667-7_2

Spéder, Zs. - Murinkó, L. - Oláh, Sz.L. (2017): Sailing close to the wind? The effects of third birth policies in post-communist Hungary. Working Papers on Population, Family and Welfare, 27. Hungarian Demographic Research Institute, Budapest. https://doi. org/10.21543/WP.2017.27

Székely Gáborné (2020): Száz év a magyarországi lakásstatisztikában (One hundred years of housing statistics in Hungary). Statisztikai Szemle (Hungarian Statistical Review), 98(6): 642-664. https://doi.org/10.20311/stat2020.6.hu0642

Szikra, D. (2016): Nem azoknak segít a CSOK, akiknek a legnagyobb szükségük lenne rá (HPS helps others than those who would need it the most). http://lumens.hu/2016/03/02/ nem-azoknak-segit-a-csok-akiknek-a-legnagyobb-szukseguk-lenne-ra/. Downloaded: 11 December 2020.

Tatay, T. - Sági, J. - Lentner, Cs. (2019): A családi otthonteremtési kedvezmény költségvetési terheinek elöreszámítása 2020-2040 (Forecast of the fiscal burdens of the Home Purchase Subsidy for Families 2020-2040). Statisztikai Szemle (Hungarian Statistical Review), 97(2): 192-212. https://doi.org/10.20311/stat2019.2.hu192

Tóth, F.- Horváthné Kökény, A. (2018): A családok otthonteremtési kedvezménye és annak várható hatásai (Home Purchase Subsidy for Families and its expected effects). Economica New, 9(2): 55-63. https://doi.org/10.47282/ECONOMICA/2018/9/2/4134 